\title{
The Outcomes of Cooperation of Kazakhstan and Turkey in the
} Field of Education

\author{
M. Tlebaldiyeva ${ }^{1}$, T. Sadikov ${ }^{2}$, G. Kamiyeva ${ }^{3}$, Z. Moldahmetova $^{4}$
}

\begin{abstract}
:
Official relations between Turkey and Kazakhstan were established in December 1990. The Minister of Culture Namik Kemal Zeybek and the Kazakh State Culture Committee signed an agreement for the carrying out of common cultural work between two countries in education system, research projects, exchange experience of experts and scholars in the practice.

This agreement regained cultural ties interrupted long time ago. The official visit of the head of the Kazakh State Culture Committee paid to Turkey on the January 31, 1991, and the cooperation agreement signed by the Minister of Health on February 14 of that year strengthened cultural relations between the two countries.

Before gaining the independence of Kazakhstan the official visit of the Turkish President Turgut Ozal to Kazakhstan on March 15 and signing the agreement "on the relationship of Kazakh Soviet Socialist Republic and the Republic of Turkey" led to the strengthening friendship Kazakh-Turkish relations and further development in this direction.
\end{abstract}

Keywords: International cooperation, education, agreement, cultural, relationship.

\footnotetext{
${ }^{1}$ Master of History, L.N. Gumilyov Eurasian National University, science_12@mail.ru

${ }^{2}$ Doctor of Historical Sciences, Associate Professor of History L.N. Gumilyov Eurasian National University, Astana, Kazakhstan.

${ }^{3}$ Candidate of Pedagogical Science Kazakh Humanities and Law Institute of the Ministry of Justice of the Republic of Kazakhstan, Astana, Kazakhstan

${ }^{4}$ Candidate of Pedagogical Science Kazakh Humanities and Law Institute of the Ministry of Justice of the Republic of Kazakhstan, Astana, Kazakhstan
} 


\section{Introduction}

The official visit of the head of the Kazakh State Culture Committee paid to Turkey on the January 31, 1991, and the cooperation agreement signed by the Minister of Health on February 14 of that year strengthened cultural relations between the two countries. Before gaining the independence of Kazakhstan the official visit of the Turkish President Turgut Ozal to Kazakhstan on March 15 and signing the agreement "on the relationship of Kazakh Soviet Socialist Republic and the Republic of Turkey" led to the strengthening friendship Kazakh-Turkish relations and further development in this direction. This agreement opened the way for the opening of embassies and the expansion of cultural ties between the two countries.

The visit of Turgut Ozal showed new faces of Kazakhstan to the Turkish society. Turkish periodicals covered the future relationship between Kazakhstan and Turkey and the official invitation of the President of Kazakhstan Nursultan Nazarbayev to Turkey. At the meeting Turgut Ozal and Nursultan Nazarbayev spoke about the issues of transition to a market economy, shared recommendations for strengthening a stable currency, ensuring the conditions for a decent investment for Turkish entrepreneurs. In his interview Turgut Ozal said on the further strengthening of relations between Turkey and Kazakhstan (Atatürik aytqan eken, 2010).

Based on resolution of the Supreme Council of the Republic of Kazakhstan of January 15, 1992, was adopted the law on "Science and scientific-technical policy of the Republic of Kazakhstan". Within the framework of the law Kazakhstani students had the opportunity to study in about 30 universities in Turkey, including a highlevel educational institution in Istanbul "Bosphorus", in Ankara "Middle East Technical University" (METU), "Bilkent" (Ergöbek, 2007).

\section{Results and discussion}

The education system in Turkey is western-style. Learning system is in the form of western Turkey. First four years are devoted to study only the subjects of main specialty, general subjects are not even taught as in the system of Kazakhstan. Of course there is an advantage that students can get full, comprehensive education. For example, from orientation to the profession a student may be able to master his skills, but the lack of progress in general background and poor logical thinking skills can complicate the process of solving problems. In the system of Kazakhstan students study to be fully trained engineers they also study all the general subjects (for example, history of Kazakhstan, philosophy, economics, mathematics, physical education, etc.).

In Turkey undergraduate students have to pass 8-10 subject-exams each semester. End-of term tests, examinations are held mainly in written form. However, the test oral form is also used. Students who are eager to study are provided with all 
necessary educational conditions. For example, all students are provided with full accommodation and all modern equipment.

For example, the graduates of the famous Fatih University work in countries such as the United States and Western Europe. Since 1992, in accordance with the international agreements Kazakh students studying in Turkish institutions of higher education will be on the Turkish government grant. According to the data of 2009, 737 students are enrolled at 27 Universities of Turkey. 544 Turkish citizens are studying in institutions of higher education in Kazakhstan. Turkey grants each year 70 Mongolian students, including 10 Kazakh youngsters living in that country. Each year, 25 percent of the state budget is allocated to science and education. Annually students enroll Colleges and universities by the one-step exam organized by the Selection and Placement Center.

The mentioned center is functioning under the Supreme Council Education organization. Foreigners wishing to study in Turkey take examinations once a year held by the Selection and Placement Center and are selected according to results. Exam questions are only available in English and Turkish. The youngsters who have got a right to be educated in Turkey are taught the Turkish language within one year in the Center of the Turkish language under the Rectorate of the University of Ankara. More than 3 million people per year get the education according to National Education Ministry. Co-education courses encompass more than 9 million participants. The work of so-called "TIKA" which is being conducted under the Turkish Cooperation and Development Administration is surprising.

According to the Secretary General of the platform "Eurasia Dialogue" Ismail Tas they are trying to promote cultural and economic ties between Kazakhstan and Turkey. There is the Rectors Association "Universities Unit" in Istanbul. Thanks to this organization there are institutions, higher education schools built under the support of Turkish entrepreneurs. In the coming years, they are going to carry out such projects. Furthermore, the Turkish side has funded the university buildings and dormitories, and other resources necessary for the construction (Nazarbayev, 2000).

Nowadays more than 200 Kazakh girls and boys are studying economics, construction, journalism, medicine and law in higher education institutions of Turkey. However most of Kazakh students in Turkey carry out their own ethnical business such as production, sewing and selling of leather goods. Since 1991 the connection between Kazakhs of Turkish origin and the Republic of Kazakhstan is progressing. One of the most important events for Kazakhs living in Turkey was the meeting held on the $28-29^{\text {th }}$ of March 1997. There is no separatism towards Kazakh community from Turkish people. The level of relationships between local people, government and administration is high.

In 2005 based on the decree of the President of the Republic of Kazakhstan «On the improvement of actions of state management authorities in terms of economic» has 
been formed the organization of Science and Technology of the Republic of Kazakhstan. The Ministry tasks were as follows:

- $\quad$ To carry out the policy in the sphere of international scientific and technical development of Kazakhstan;

- To coordinate the training of scientific and pedagogic personnel of Kazakhstan;

- To organize international cooperation in the scientific and technological sphere of Kazakhstan.

Turkey is closer to Kazakhstan on cultural, religious and linguistic issues. The relations of expat living in Europe and Turkey are still strong. Indeed, the European expat consists of those who moved from the territory of Turkey. In this context interpersonal relations are seen since representatives of the Kazakh expat give their children Turkish names, traditions and customs, holidays resemble Turkish. It's natural, because Turkic peoples were always close since ancient times and living in Turkey is extremely contributed to the culture of the Kazakhs. The ties of European Kazakhs with Turkey are stronger rather than Kazakhstan's. Many of them live in Turkey, China, Altai.

The Fund of Turkish Kazakhs is actively functioning in Istanbul. The Istanbul Municipality allocated premises for the Fund. Fund managers pave the way to learn Kazakh, and organize meetings with the representatives of Kazakhstani culture and art. In the home of the offices of the Fund there are Kazakh yurt, the welfare of the Kazakh things, assembled literature which are shown on various celebrations, meetings, concerts. Fund organized the Children's Dance Ensemble which take part at various concerts and presentation.

There is "Arman" magazine published by the Fund. There are some difficulties in material take-off for magazine since there are few authors who can cover the full life of the country. Turkish Kazakhs face challenges in assembling information in Kazakh. The relationship between Kazakh expat and municipality is very good. The head of the local government distinguishes Kazakhs living in obedience to the law, and their appreciation for the hard work.

The youth speaks Turkish and the language of instruction is also Turkish. The Fund itself organized teaching Kazakh. In 2005 the teacher of Kazakh came to Istanbul University and the teaching language of youth was organized. There are some difficulties related to different Alphabet graphics. Books delivered from Kazakhstan were written in Cyrillic alphabet. There is lack of specialists who can teach language in this graphics. This statement made the delivery of Cyrillic written books from Kazakhstan senseless (Qaliev, 2010).

Perhaps afore said statements, established spiritual values, widely spread political and economic interests, cooperation relations are fastening the progress in 
relationships of the two countries. Kazakhstani scholar M.B. Mukhamedov who is aware of Kazakhstan-Turkey relationships said that there was a need in political support of Turkey. Of course, common mental, lingual, cultural and historic aspects play a great role between relations of Kazakh and Turkish nations. Taking into consideration these points Turkeys were represented as the guarantors for Kazakhstan to obtain credits from western resources as Turkey is very respectful country on the worldwide arena. At the same time one of the factors which accelerated the Turkey-Kazakhstan relationships is mutually beneficial establishment of cooperation in the sphere of trade economy.

In 2009, November 19, on the meeting of the Ambassador of Kazakhstan in Turkey Beibit Isabayev and ex-president of Turkey Suleiman Demirel were shared opinions on relationships between two countries and the internal and foreign policy of Turkey. Ex-president S. Demirel expressed his positive attitude towards investments from Kazakhstan to Turkish economy and emphasized Turkish government's readiness to support it. The representatives of the two countries discussed future strategies in improving bilateral relations. At the same time there were approved cooperation agreements in terms of recommencement of TURKSOY which is considered as mini UNESCO of Turkish world.

On May 1-3, 2007, the Minister of Education and Science of the Republic of Kazakhstan Zhanseit Tuimebayev paid an official visit to the Republic of Turkey. Kazakhstani Minister held bilateral talks with his counterparts during the official visit, discussed the issue of expanding the horizons of cooperation in the field of education. The Kazakhstani delegation visited Turkish Scientific and Technological Research Structure and Higher Education Council and considered the ways of development of cooperation with them.

Negotiations between the two countries' Ministers of Education encompassed the current assessment of relations in the field of higher education and some solutions to several issues. In particular, because of negotiations it was signed a Memorandum of Cooperation in the field of professional-technical education. According to the memorandum, the part of the Republic of Turkey agreed to share knowledge and experience in the field of science with the Kazakh side. Especially the experience of Turkey is interesting on the part of the goods, textiles, tourism, and several technical vocational and technical training areas.

On the meeting with the members of the structure led by the Chairman Professor Nuket Yetïş of TUBITAK of the Minister of Education and Science of the Republic of Kazakhstan was said that they were interested in working together with the Turkish side, including invitation to participate in common programs within the framework of the EU.

On the meeting with the Chairman of the Board of Higher Education of the Republic of Turkey Erdogan Tezïçpen were discussed ways to increase cooperation between 
the two countries' institutions of higher education. The sides highlighted the point of organizing scientific symposiums and other events between the two countries' universities. Kazakhstani Minister expressed the willingness to cooperate with a number of prestigious universities of Turkey in accordance with the standards of the European countries.

Currently, about 700 Kazakh students are studying in Turkey. In turn, more than 500 Turkish students are studying in Kazakhstan. So far, about 900 Kazakhstani youth graduated from Turkish universities. In Chapter 10 of "Education Act" №319 of the Republic of Kazakhstan of July 27, 2007, the services of international cooperation in the field of education and economic activity were considered. They are as follows:

1. International cooperation in the field of education of the Republic of Kazakhstan is carried out based on legislation of the Republic of Kazakhstan and international treaties of the Republic of Kazakhstan.

2. The organization of education in accordance with the competent authority in the field of education in coordination with own peculiarities has the right to access foreign education, to establish direct links with scientific and cultural organizations and foundations, to make bilateral and multilateral terms on cooperation, to participate in the exchange international programs of students, undergraduates, doctoral students, the teacher and workers, to enter international non-governmental organizations (associations). Military educational institutions in accordance with the international treaties and agreements with foreign citizens have the right to carry out training of specialists in a row. Educational organizations shall have the right to engage in foreign economic activity in the manner specified by the charter specified in educational institutions and laws of the Republic of Kazakhstan.

3. The order of the implementation of international cooperation in the educational institutions of the Republic of Kazakhstan established by the authorized body in the field of education.

4. The establishment of International and foreign educational institutions and (or) branches in the Republic of Kazakhstan is carried out based on international agreements or in accordance with the decision of the Government of the Republic of Kazakhstan.

5. Licensing, accreditation and certification of international institutions and other states or their legal and educational institutions, their affiliates in the territory of the Republic of Kazakhstan unless stipulated by international treaties ratified by the Republic of Kazakhstan will be carried out in accordance with the laws of the Republic of Kazakhstan (Tuimebayev, 2010).

The head of state addressed the people of Kazakhstan on March 6, 2009, in his message "Through Crisis to Renovation and Prosperity" specific tasks for the implementation of the further modernization of the economy and to ensure the development of the country in the post-crisis employment strategy. During this difficult period the system of education and science is developed due to the constant attention and support of the head of state. The education budget in 2009 comprised 
702,0 billion tenge, compared to 2008 increased by $9.5 \%$ (in 2008 - 641,1 bln. tenge). Because of the funds allocated for education 20 thousand students are studying abroad. Taking into consideration these aspects the education system of our country and its pedagogic personnel's quality must be defined in accordance with the strategy of innovative and industrial development (Tuimebayev, 2010).

In 2009, October 22, within the frameworks of the official visit of the President of the Republic of Kazakhstan N. Nazarbayev it was signed cooperation agreement in the sphere of science and technology between the Minister of Education and Science of the Republic of Kazakhstan and Turkey. In the terms of this agreement there is cooperation in conducting common scientific and research projects, exchange of scholars and experts, carrying out scientific conference and symposiums, and interchange of scientific and technical information and documents. In that order after defining the field of cooperation of two parties there is commission which prepares proceedings and programs in carrying out the agreement terms and implements common projects within the frameworks of the program "International cooperation in the field of science on 2010-2012" (Sawdabaev, 1996).

\section{Conclusion}

As Zh. Tuimebayev pointed out since 1992 there are more than 4 thousand Kazakhstanis who graduated from Turkish universities. As a sample of friendship between two states under support of heads of states there was opened Yassaui International Kazakh-Turkish University which became one of the prestigious universities. There are also S. Demirel Private University and Foreign Languages and Business University as well as 30 Kazakh-Turkish lyceums and 9 secondary schools (Qalïev, 2010).

To strengthen scientific, education and cultural relations between Turkey and Kazakhstan the two countries share the same high school in the city of Turkestan the Yassaui International Kazakh-Turkish University. To make University of Turkic states Turkish government during the years 1993-2001 donated 86 million dollars. For the past 10 years about 25 thousand people from Kazakhstan went through internship in the Republic of Turkey.

Turkey's economic potential is higher than Kazakhstan's and it has its own way to reach international market. As well as it has high reputation in the European Community. Therefore, a model of economic reform to adjust the laws of market relations will play a huge role for Kazakhstan. Consequently, economic, political and cultural spheres of further development of relations contribute to the strengthening of the economic and social sectors of the two countries. Turkish culture, education, ecology, medicine, joint peace, military, political programs contribute to promotion of mutual desire to strengthen regional economic alliances on a global arena. 


\section{References:}

Ergöbek, Q. 2007. Your elbow. Sovereign Kazakhstan.

Nazarbayev, N. 2000. Our choice is unity and integration. Kazakhstan Pravda, 321.

Qaliev, N.Q. 2010. Jahandw: the quicksand and the boat. Kazakh folklore, 1.

Tuimebayev, Zh.K. 2010. The main indicator of your interest in the Jane Gilmore system of Science of the Republic of Kazakhstan. Astana. 